\title{
Halal Supplement: A Perspective of Muslim Millennial Generation
}

\author{
Nurdin Sobari ${ }^{1}$, Hardius Usman², Sunarmo ${ }^{3}$ \\ \{ ${ }^{1}$ nurdin.sobari@ui.ac.id, ${ }^{2}$ hardius@stis.ac.id, ${ }^{3}$ sunarmo.ep@ gmail.com $\}$ \\ ${ }^{1,2,3}$ School of Strategic and Global Studies, Universitas Indonesia, Indonesia
}

\begin{abstract}
The healthy lifestyle has been becoming an integration among the millennial generation. This is in line with a Centre for Strategic and International Studies (2017) survey, which states that sports and exercises are most interesting activities and a source of happiness for the millennials.

The awareness towards health indirectly affects to the increasing the wellness of sub-sector of healthy food product, supplements, and weight loss nutrients industry. A report from Global Wellness Economy Monitor (2017) states that it has been growing 6,2 percent in 2015 to become U\$D 647.8 billion.

Based on the above result, the authors have been interested to conduct a specific study regarding the perspective of Muslim millennials. The number of Muslim in Indonesia is 207.176 .162 people in which 24,20 percent or 61,68 million of them are millennial generations. In addition, halal labeled- supplement is a new market in the country. These are reasons why the study conducted.

This study is an intention analysis of Muslim millennials (18 - 37 years old) who stay in the city of Jakarta, Bogor, Depok, Tangerang, and Bekasi towards the halal labeled-supplement products by using Push, Pull, and Mooring (PPM) theory by Bansal (2005). The result of the research indicates that only variables of quality, switching behavior, subjective norms, and packaging are positively significant on switching intention; while other variables are insignificant. Moderating variables generally not all have a relationship between pull, push and switching intention. The result can be a reference to producers of halallabeled supplement producers for increasing market shares to Muslim millennial. For the governments, especially BPOM and LPPOM MUI, it is suggested to facilitate the producers in obtaining halal certification services and referring to law No.33 of 2014 concerning halal product assurance.
\end{abstract}

Keywords: Muslim millennial generation; halal - labeled supplement; Push, Pull and Mooring (PPM)

\section{INTRODUCTION}

The urban society is always having a great deal with daily routines mainly working, both in the formal and informal sector. Such conditions would be exhausting and even indirectly change their lifestyle, including psychological and health area. 
Health issues become very important in the 21 st century, especially for generation $\mathrm{Y}$ or millennial generation. According to www.urbandictionary.com, the millennial generation is a generation that was introduced after the 2nd World War, on 2 September 1945, besides other demographic groups like the baby boomer generation, generation $\mathrm{X}$, and generation $\mathrm{Z}$. Millennial generation refers to those born from 1981 to 2000 or who are currently aged between 18 to 37 years. In addition, Goldman (2013) also asserts that the millennial generation today are more committed to healthy living by exercising and eating nutritious food.

Based on Central Bureau of Statistics (BPS) 2010 census, it was noted that millennial generation amounted to 61.68 million people or 24,20 percent (aged 16 - 30 years) of the total Indonesian population. A large number of millennial generation in Indonesia has been putting awareness in the healthy lifestyle which becomes an integral whole. This is in line with the result of research conducted by Centre Strategic and International Studies (2017) among the millennials which states that sports are the most interesting activities and health is one of sources of happiness.

Health in this perspective is better known as wellness. This research is corroborated by Global Wellness Economy Monitor (GWI) 2017 report on the development of the world's wellness sub-sector. The Global Wellness Institute (GWI) defines wellness as daily, active pursuit of healthy lifestyle. The Wellness Economy growth is presented in Table 1:

Table 1. Wellness Economy Growth in the world

\begin{tabular}{|l|l|l|l|l|}
\hline \multirow{2}{*}{ No. } & \multicolumn{1}{|c|}{ Sub-sector of Wellness Industry } & \multicolumn{2}{|c|}{$\begin{array}{c}\text { Market Size } \\
\text { (US\$ billions) }\end{array}$} & $\begin{array}{l}\text { Average } \\
\text { Annual } \\
\text { Growth Rate }\end{array}$ \\
\cline { 3 - 5 } & & $\mathbf{2 0 1 3}$ & $\mathbf{2 0 1 5}$ & \\
\hline 1 & Preventive \& Personalized Medicine and Public & & & \\
\hline 2 & Fitness \& Mind-Body & 446.4 & 542.0 & 10.2 \\
\hline 3 & Wellness Lifestyle Real Estate & 100.0 & 118.6 & 8.9 \\
\hline 4 & Wellness Tourism & 494.1 & 563.2 & 6.8 \\
\hline 5 & Healthy Eating, Nutrition, \& Weight Loss & & & \\
\hline 6 & Complementary \& Alternative & & & \\
\hline 7 & Workplace Wellness & 40.7 & 43.3 & 3.1 \\
\hline 8 & Spa Economy (Spa Facilities) & 94.0 & 98.6 & 2.5 \\
\hline 9 & Thermal/Mineral Springs & 50.0 & 51.0 & 1.0 \\
\hline 10 & Beauty \& Anti-Aging & $1,025.6$ & 999.0 & -1.3 \\
\hline Wellness Economy & $\mathbf{3 , 3 6 7 . 8}$ & $\mathbf{3 , 7 2 4 . 4}$ & $\mathbf{5 . 2}$ \\
\hline
\end{tabular}

Source: Global Wellness Economy Monitor report, 2017

Table 1 shows the development of the wellness industry sub-sector in 2013 and 2015 . There can be seen that the highest growth percentage is the sub-sector of Preventive \& Personalized Medicine and Public Health, which is $11.1 \%$. Meanwhile, Healthy Eating, Nutrition, \& Weight Loss rose 6.2 percent in 2015 to U\$ 647.8 billion.

From the previous data, it shows that this sector has great demand in the community, including the Muslim millennials. The number of the Muslim population of Indonesia based on Census Bureau of Indonesia (2010) is 207.176.162 people of total population 237.641.326 people, which 24,20 percent or 61,68 million of the total number is the millennial generation. 
As Indonesia is a Muslim-majority country, Indonesian consumers of supplements should consider its source. Supplements have to be labelled as halal. Halal labeling on supplement products in Indonesia, per 2018, has covered 161 types of products (http://www.halalmui.org). The halal regulation of a product is contained in Law No.33 of 2014 concerning Halal Products Assurance. To be regulated in the law, the practice of halal labeling of a product is carried out by the Assessment Institute for Foods, Drugs and Cosmetics, the Indonesian Council of Ulama (LPPOM MUI). The purpose of labeling is to provide certainty of halal status to reassure consumers in consuming it.

A halal certificate is important to Muslim consumers. Therefore, there are many researchers that underlie the perception of Muslim society in consuming halal products, such as Norafni et al (2015) who found that advertising, knowledge, and behavior have a significant effect on halal cosmetics and personal care. This is similar to that of Arshia and Muhammad (2011) but added subjective norms and religiosity norms. In addition, Afzaal et al (2016) also found that halal brand image, halal brand satisfaction, halal brand trust, and the loyalty of halal brand has a significant effect on the intensity of the purchase.

Based on their studies, generally only see the intention of purchasing halal products without seeing the behavior of switching intention from one product to another product. One theory for measuring switching intention is Push-Pull and Mooring (PPM). PPM is a theory that developed by Bansal et al (2005) in the marketing field. According to Bansal et al (2005), PPM is the theory of consumer behavior switching caused by three factors i.e. push, pull, and mooring. The push is the effect that motivates people to abandon their old product. This effect influenced by low quality, low satisfaction, low value, low commitment, and high prices. Secondly is the pull effect. A pull effect is a positive factor that causes the consumer's intensity to switch, the cause being an attractive offer from other manufacturers. And the last is mooring effect. A mooring is an effect that does not support the transition, it is caused by an unfavorable attitude towards switching, unfavorable subjective norms, high switching cost, infrequent prior switching behavior, and low variety seeking.

Based on the above problems, the authors tried to use the PPM model to measure the intention of switching to halal-labeled supplement products. This is because halal-labeled supplements are a new market and potential in Indonesia, particularly for the millennial generation who are very aware of healthy.

\section{LITERATURE REVIEW}

\subsection{Millennial Generation}

The millennial generation or generation Y according to Michael (2017) are those who were born between 1981 and 2000; or who are currently aged between 18 and 37 years. However, according to Michael (2017), the pattern of the millennial generation in each country, like Japan, Asia, and a part of Europe, has differences based on its culture, politics, and economic conditions. The millennial generation is characterized

as having high social awareness, ambitious, and preferring something new (The West Midland Family Center, 2017). The most fundamental difference between the generation Y and the previous generations is the knowledge of information and technology, especially on the use of electronic devices. This is as mentioned by Gurau (2012), that the millennial 
generation is a generation that is characterized by the high literacy of internet, technology, and media. In addition, according to Kim (2008) they are a group of confident, optimistic, competent people with high multitasking capabilities. This is because they were born during the period of economic growth and because of the strong influence of modernization and culture (Parment, 2010).

\subsection{Halal Supplement Product}

Food and Drug Supervisory Agency (BPOM) defines supplement product as the basic nutritional supplement, containing one or more ingredients of vitamins, minerals, amino acids or other ingredients (derived from plants or non-plants) that have nutritional value and/or physiological effects in concentrated quantities. As a Muslim majority country, in Indonesia, halal certification is important to the consumed product (Ambali and Bakar, 2012, Ali et al, 2018), including supplement products. Halal certification in Indonesia is regulated by Institute for Assessment of Food, Drugs, and Cosmetics of Indonesian Ulama Council (LPPOM MUI). As it is known, halal label supplements have just newly entered the Indonesian market.

\subsection{Push-Pull and Mooring Theory (PPM)}

The push-pull theory first introduced in 1885 on the application of migration law that specializes in the field of demography (Ravenstein, 1885). In the law, mentions human migration from one place to another which is affected by the push and pull. Push effects stem from their negative living conditions such as poor economic conditions, poor weather, and difficulty finding employment. While the pull effect comes from the positive attraction at the destination such as better job opportunities and higher wages (Lee, 1966). Although the pushpull theory expressed by Ravenstein (1885) and Lee (1966) is quite representative of migration theory, they do not see any psychological factor in deciding whether to migrate or settle. Starting from that reason, Moon (1995) insert mooring variables as the intervening variable in the theory, this variable is a moderate variable that serves as a determinant of migrating or not migrating. From here, comes a new theory called Push - Pull and Mooring (PPM). Over the time, his theory was applied in science various disciplines, one of which is marketing field. Implementation of PPM in marketing science was first performed by Bansal (2005) who examines the migration of hair stylish customers and car repair services.

\subsubsection{Push}

The push effect is the effect that drives a person to leave the residence, in which case the origin has a negative influence allowing one to move elsewhere (Stimson and Minnery 1998). Push indicators according to Bansal et al (2005) ie low quality, low satisfaction, low value, low trust, low commitment, and high-cost perception. This is almost the same as stated by Jung et al (2017) and Avus et al (2014) which mentions that the negative indicators of the push on service providers such as service failures, employee performance, and prices include a level of trust and satisfaction. While Bill (2015) and Chandra (2011) mentioned only satisfaction variable in the push effect. Another method using by Afzaal et al (2018) is Theory 
of Planned Behavior (TPB), which is brand quality effects to the halal brand image, halal brand satisfaction, halal brand trust, halal brand loyalty, and buying intent. All of the research shows that the push effect positively influences on switching intention, accordingly, the following hypothesis is proposed:

$\mathrm{H}_{1}$ : Price, quality, satisfaction, and brand equity positively effects on switching intention to halal-labeled supplement.

\subsubsection{Pull}

The pull effect is a positive effect that causes consumers to switch to another provider's service. The pull indicator used by Bansal et al (2015) and Nico (2015) is an alternative attractiveness, but Jung et al (2017) adding the variable of opportunity for alternative and pricing benefits. This appeal comes from other service providers. Factors that cause consumers to switch to other services by Ye and Potter (2011) are lower prices, ease of use and feelings of security. These three things become consumer considerations in switching but he also sees another important enough aspect of assessing whether the new service is better than the previous service or not.

The hypothesis of our research is:

$\mathrm{H}_{3}$ : Alternative Attractiveness, pricing benefits and packaging effects on switching intention to halal-labeled supplement

\subsubsection{Mooring}

The mooring effect is a fairly complex concept of migration and is the development of a simple push-pull concept (Boyle, 1998). The approach to this effect leads more to the psychological factors and cultural value of the consumer in deciding whether to migrate to another service product or not. Hou et al (2011) also state that mooring is cannot be explained by push and pull variables. Bansal et al (2005) use mooring indicators such as unfavorable attitude toward switching, unfavorable subjective norms, high switching costs, infrequent prior switching behavior, low variety seeking, and involuntary choice (Jung, 2017, Hou, 2014). Therefore, the following hypothesis is proposed:

$\mathrm{H}_{2}$ : Switching cost, attitude switching, and subjective norms effects on switching intention to halal-labeled supplement

$\mathrm{H}_{4}$ : The mooring variable significantly moderates the relationship between the push effect and switching intention to halal-labeled supplement

$\mathrm{H}_{5}$ : The mooring variable significantly moderates the relationship between the pull effect and switching intention to halal-labeled supplement

Table 2. Previous research of PPM and purchase intention to halal-labeled product

\begin{tabular}{lllll}
\hline \multicolumn{2}{c}{ Authors } & Theory & \multicolumn{1}{c}{ Results } & Object \\
\hline Harvir & S Bansal, & PPM & Overall, the PPM indicator significantly & Customers of \\
Shirley & F.Taylor, & & influences the intention of switching to other & Hairstylist and car \\
Yannik & St. James & & hair stylish and other car repair services. While & repair services \\
$(2005)$ & & & on moderation variable not found any & \\
\hline
\end{tabular}




\begin{tabular}{|c|c|c|c|}
\hline & & significant influence & \\
\hline $\begin{array}{l}\text { Jishim Jung, Heesup } \\
\text { Han, and Mihae Oh } \\
\text { (2017) }\end{array}$ & PPM & $\begin{array}{l}\text { All of the PPM indicators directly affect } \\
\text { significantly to the switching intention to other } \\
\text { airlines, but in the moderation variable there is } \\
\text { no relationship between variables }\end{array}$ & $\begin{array}{l}\text { Customers of } \\
\text { airlines services }\end{array}$ \\
\hline $\begin{array}{l}\text { Bill Jezy Nico } \\
\text { Papalapu (2015) }\end{array}$ & PPM & $\begin{array}{l}\text { Push variable: satisfaction (X1), Pull: alternative } \\
\text { attractive (X2), and Mooring: switching cost } \\
\text { (X3) has the significant effect on switching } \\
\text { intention to other pay-tv services }\end{array}$ & $\begin{array}{l}\text { Customers of } \\
\text { Pay-Television } \\
\text { (TV) service }\end{array}$ \\
\hline $\begin{array}{lr}\text { Afzaal } & \text { Ali, } r \text { Guo } \\
\text { Xioling, } & \text { and } \\
\text { Mehkar } & \text { Sherwani } \\
(2018) & \end{array}$ & TPB & $\begin{array}{l}\text { Brand quality positively affects the Halal brand } \\
\text { image, Halal brand satisfaction, Halal brand } \\
\text { trust, Halal brand loyalty, and buying intent. } \\
\text { Similarly, the Halal brand image, Halal brand } \\
\text { satisfaction, Halal brand trust, and loyalty of the } \\
\text { halal brand that significantly influence to the } \\
\text { intention of purchasing a halal brand of } \\
\text { consumers. }\end{array}$ & $\begin{array}{l}\text { Consumers of } \\
\text { Halal - labeled } \\
\text { product }\end{array}$ \\
\hline $\begin{array}{l}\text { Liza Agustina M, } \\
\text { Carolina Chandra P } \\
\text { (2011) }\end{array}$ & PPM & $\begin{array}{l}\text { The results of this study indicate that service } \\
\text { quality has a significantly positive on } \\
\text { satisfaction and has a significantly negative on } \\
\text { switching intention. While customer satisfaction } \\
\text { does not give a significant influence on } \\
\text { switching intention }\end{array}$ & $\begin{array}{l}\text { Customers of } \\
\text { Boardinghouse } \\
\text { service }\end{array}$ \\
\hline $\begin{array}{lr}\text { Bee Li } & \text { Yeo, } \\
\text { Hj. } & \text { Naina } \\
\text { Mohamed, } & \text { and } \\
\text { Mazzini } & \text { Muda } \\
(2016) & \\
\end{array}$ & TCV & $\begin{array}{l}\text { Perception of value, customers satisfaction and } \\
\text { brand value have an important role in } \\
\text { motivating Malaysian consumers when buying } \\
\text { halal cosmetic products. }\end{array}$ & $\begin{array}{l}\text { Consumers of the } \\
\text { Halal-labeled } \\
\text { cosmetic product }\end{array}$ \\
\hline $\begin{array}{l}\text { Avus Hou, Rong- } \\
\text { An Shang, Chin- } \\
\text { Chun Huang, Kuo- } \\
\text { Long Wu }\end{array}$ & PPM & $\begin{array}{l}\text { The push, mooring, and pull variables have a } \\
\text { significant effect and build a solid framework } \\
\text { for influencing the intention to other social } \\
\text { networks. }\end{array}$ & $\begin{array}{lr}\text { Consumers } & \text { of } \\
\text { Social } & \text { media } \\
\text { networks } & \end{array}$ \\
\hline $\begin{array}{lr}\text { Abdul } & \text { Raufu } \\
\text { Ambali, } & \text { Ahmad } \\
\text { Naqiyuddin } & \text { Bakar } \\
(2012) & \end{array}$ & ТРB & $\begin{array}{l}\text { Level of religiosity, halal labeling, exposure, } \\
\text { health reasons are a potential source of Muslim } \\
\text { consciousness about halal consumption. } \\
\text { However, healthy reasons are the predictors that } \\
\text { most contribute to the awareness of eating halal } \\
\text { food. }\end{array}$ & $\begin{array}{l}\text { Consumers } \\
\text { halal food }\end{array}$ \\
\hline $\begin{array}{l}\text { Aiedah Abdul } \\
\text { Khalek (2013) }\end{array}$ & ТPB & $\begin{array}{l}\text { Subjective norms (X1), attitude (X2) and } \\
\text { behavioral control (X3) have a positive } \\
\text { relationship with behavior intention (Y). In } \\
\text { addition, the result of the study mention that the } \\
\text { respondent agreed if food outlets should include } \\
\text { the halal label in his outlets }\end{array}$ & $\begin{array}{l}\text { Young consumers } \\
\text { to halal food } \\
\text { outlets }\end{array}$ \\
\hline $\begin{array}{l}\text { Norafni Farlina, } \\
\text { Zurina Shafil, } \\
\text { Syahidawati } \\
\text { Shahwan (2015) } \\
\end{array}$ & ТPB & $\begin{array}{l}\text { Advertising (X1), knowledge (X2), attitude } \\
\text { (X3) have a significant effect on awareness and } \\
\text { perception of Malaysia's Muslim in use halal } \\
\text { cosmetic and personal care products }\end{array}$ & $\begin{array}{l}\text { Consumers of } \\
\text { Halal cosmetics } \\
\text { and personal care } \\
\text { product }\end{array}$ \\
\hline
\end{tabular}

Based on previous studies (table 2), generally using three theories such as Push- Pull and Mooring (PPM), the theory of planned behavior (TPB), and theory of consumption value 
(TCV). Different characteristics mainly visible on research object and research modeling. Though theories and research modeling are quite complex, there is no specific link between PPM theory and perception to consumption goods mainly halal supplement products. Therefore, authors interested in this topic and correlated to Muslim millennial generation.

\section{CONCEPTUAL FRAMEWORK}

Based on the background and theory, this is our research framework (figure 1) as follow:

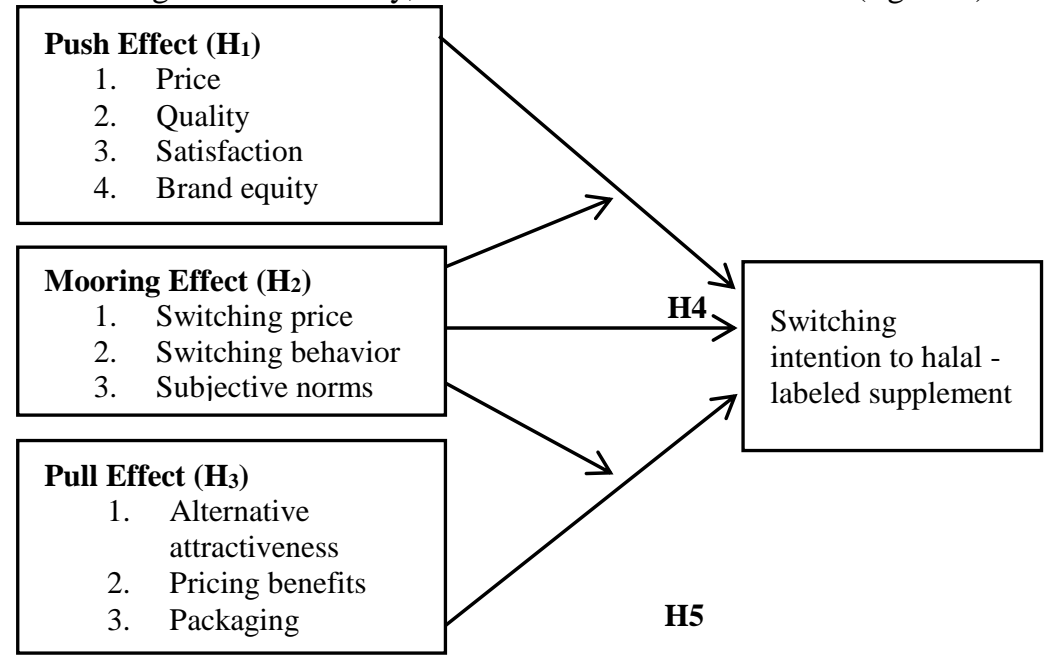

Figure 1. Research framework

The research framework of this research is presented in a structural equation modeling, in Fig 1. consist of three (3) independent indicators are push, mooring, and pull effect. and one (1) dependent indicator is switching intention. Push is measured by four variables such as price, quality, satisfaction, and brand equity. The mooring effect consists of switching price, switching behavior, and subjective norms. The last effect is pull, this effect divided into alternative attractiveness, pricing benefits, and packaging. Each of the variables measured by some item questions (see Appendix A). Our research framework adopted from Bansal et al (2005), Jung et al (2017).

\section{METHODOLOGY}

The study sample was Muslim consumers, 18 - 37 years old, live in in the city of Jakarta, Bogor, Depok Tangerang, Bekasi (Jakarta and ring urban areas) who have been regularly using halal supplement product or never used it altogether, and not sure that entire supplement purchased are all halal-labeled. The city becomes a research place because based on Survey Centre Strategic and International Studies (2017) about interesting issues for the millennial generation. The survey finding that health is a source of happiness by urban society in the big city, one of them is the city of Jakarta and the surrounding area. This study uses online questionnaires collecting data from 189 respondents. The 189 are the response from consumers who are not sure the supplement they are currently consume come with the halal 
label. The collected data were analyzed using SPSS 17 and Amos 20. The variables used in this study consists of 3 main indicators namely push effect, mooring effect, and pull effect. Each of them divided into several variables and question indicators. The derivative of the indicator is formed in a questionnaire whose answer is a 5-point Likert scale.

\section{RESULT}

\subsection{Respondents' Demographic}

The respondents comprised mainly of female, which is 107 (57\%) and male 82 participants $(43 \%)$. The analysis also showing about their job. Many of them work as a private employee with composition 63 respondents or $33 \%$, followed by student college $31 \%$, government employee 14\%, entrepreneur 13\%, and the other $9 \%$. This demographic table also demonstrates the monthly expenditure, most of them earn $>2-3$ IDR million (31\%), $1-2$ IDR million (26\%), 3 - 4 IDR million (15\%), < 1 IDR million (15\%), > 5 IDR million (10\%), and the last is $>4-5$ IDR million i.e. 13\%. All of the respondents come from the city of Jakarta, Bogor, Depok, Tangerang, and Bekasi (see Table 4).

Table 4. Respondents' Demographic

\begin{tabular}{|l|l|l|}
\hline \multicolumn{1}{|c|}{ Categorized } & \multicolumn{1}{c|}{ Information } & \multicolumn{1}{c|}{ Number of respondents } \\
\hline \multirow{4}{*}{ Jender } & Male & $82(43 \%)$ \\
\cline { 2 - 3 } & Female & $107(57 \%)$ \\
\hline \multirow{5}{*}{ Mob } & Student college & $58(31 \%)$ \\
\cline { 2 - 3 } & Private employee & $63(33 \%)$ \\
\cline { 2 - 3 } & Government employee & $27(14 \%)$ \\
\cline { 2 - 3 } & Entrepreneur & $24(13 \%)$ \\
\cline { 2 - 3 } & Others & $17(9 \%)$ \\
\hline \multirow{5}{*}{ Sonthly expenditure } & $<1$ million & $29(15 \%)$ \\
\cline { 2 - 3 } & $1-2$ IDR million & $50(26 \%)$ \\
\cline { 2 - 3 } & $>2-3$ IDR million & $58(31 \%)$ \\
\cline { 2 - 3 } & $>3-4$ IDR million & $29(15 \%)$ \\
\cline { 2 - 3 } & $>4-5$ IDR million & $5(3 \%)$ \\
\cline { 2 - 3 } & $>5$ IDR million & $18(10 \%)$ \\
\hline
\end{tabular}

Source: primary data, author processed.

In addition to the demographics of respondents, the researchers also inquire about the impact of exercise on health. Of the 189 respondents, $80 \%$ or 151 participants answered strongly agree, while $20 \%$ (38 participants) answered agree. the percentage indicates that the Muslim millennial generation in the cities of Jakarta, Bogor, Depok, Tangerang, and Bekasi still consider the importance of exercise as one of the factors supporting a healthy life, this similar with the survey of Center Strategic and International Studies (2017) which states that exercise is the activity most favored by millennial generation. (see figure 2): 


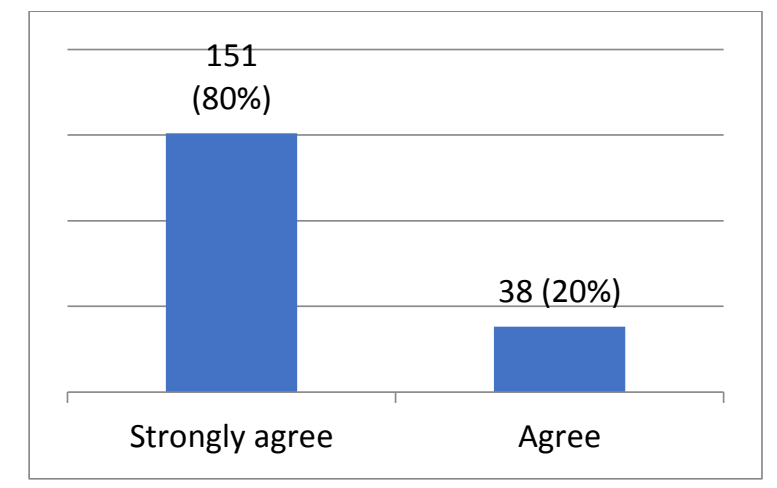

Figure 2. Survey of the impact of exercise on health

The researchers also asked about the historical illness of the respondents, as many as 47 respondents $(25 \%)$ answer had the illness and 142 respondents $(75 \%)$ did not have. So, it can be concluded that most millennial generations consume supplements not because they have an illness but to maintain a healthy body. This is in line with the purpose of food supplement by Decision of the Head of the Food and Drug Supervisory Agency of the Republic of Indonesia (BPOM) Number HK 00.05.23.3644 2014 which is to complement the needs of nutrients for the body. (see figure 3)

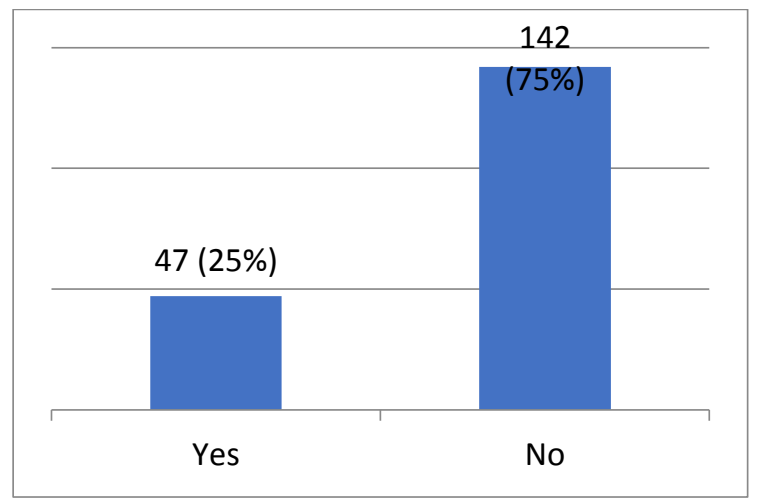

Figure 3. The historical illness survey

After knowing about the historical illness of respondents, we try to survey for information of supplement consuming (see Table 5). Duration of consuming supplements as much as 125 respondents $(66 \%)$ consume it $<1$ year while 64 respondents $(34 \%)$ consume more than 1 year. In terms of frequency, 95 respondents $(50 \%)$ took supplements at a certain moment, 33 respondents $(17 \%)$ consumed daily, 15 respondents $(8 \%)$ consumed 1 - 3 times a month, 35 respondents (19\%) 1 - 3 times a week, and 11 respondents $(6 \%)$ consume $14-6$ times a month. In terms of monthly expenses, 156 respondents (83\%) set aside a budget <IDR 300,000 to buy supplements, 23 respondents (12\%) set aside money> IDR300,000 while 10 respondents (5\%) allocated budget> IDR 500,000 to buy product supplement. 
Table 5. Data of supplement consuming

\begin{tabular}{|l|l|l|}
\hline Items & Information & $\begin{array}{l}\text { Number of } \\
\text { respondents }\end{array}$ \\
\hline \multirow{2}{*}{$\begin{array}{l}\text { Duration of } \\
\text { consuming }\end{array}$} & $<1$ year & $125(66 \%)$ \\
\cline { 2 - 3 } fonsumption & $>1$ year & $64(34 \%)$ \\
\cline { 2 - 3 } & At a certain moment & $95(50 \%)$ \\
\cline { 2 - 3 } & Every day & $33(17 \%)$ \\
\cline { 2 - 3 } & $1-3$ times a month & $15(8 \%)$ \\
\cline { 2 - 3 } & $1-3$ times a week & $35(19 \%)$ \\
\cline { 2 - 3 } & $14-6$ times a month & $11(6 \%)$ \\
\hline \multirow{2}{*}{$\begin{array}{l}\text { Monthly budget for } \\
\text { a supplement }\end{array}$} & < IDR 300.000 & $156(83 \%)$ \\
\cline { 2 - 3 } & $>$ IDR300.000 & $23(12 \%)$ \\
\cline { 2 - 3 } & $>$ IDR 500.000 & $10 \%)$ \\
\hline
\end{tabular}

Source: primary data, author processed.

\subsection{Validity and Reliability Test}

From the above output obtained that all items of push, mooring and pull has a value above 0.3 , it can be concluded all questions on the item is valid (see table 6 part of Total Pearson Correlation).

Test reliability as a result of the Cronbach alpha test. In determining a reliable or unusable limit of alpha value 0.6 (Ghozali, 2006) from the test output seen that the variable value of push reliability is 0.828 , it means this variable has good reliability. While for the variable of mooring, pull, and intention has value $0,780,0,716$ and 0,682 meaning its reliability including acceptable category. (see Table 6 part of Reliability).

Table 6. The result of validity and reliability test

\begin{tabular}{|c|c|c|}
\hline Scale items & Reliability & $\begin{array}{l}\text { Total Pearson } \\
\text { Correlation }\end{array}$ \\
\hline \multicolumn{3}{|l|}{ Push } \\
\hline \multicolumn{3}{|l|}{ Price } \\
\hline HAR1 & & $0.724 * *$ \\
\hline $\begin{array}{l}\text { HAR2 } \\
\text { HAR3 }\end{array}$ & & $\begin{array}{l}0.632 * * \\
0.596 * *\end{array}$ \\
\hline \multicolumn{3}{|l|}{ Quality } \\
\hline $\begin{array}{l}\text { KUA1 } \\
\text { KUA2 }\end{array}$ & 0.828 & $\begin{array}{l}0.675^{* *} \\
0.484^{* *}\end{array}$ \\
\hline KUA3 & & $0.702 * *$ \\
\hline \multicolumn{3}{|l|}{ Satisfaction } \\
\hline KEP1 & & $0.530 * *$ \\
\hline KEP2 & & $0.617 * *$ \\
\hline $\begin{array}{l}\text { Brand equit } \\
\text { EM1 } \\
\text { EM2 }\end{array}$ & & $\begin{array}{l}0.635 * * \\
0.674 * *\end{array}$ \\
\hline
\end{tabular}

Mooring 


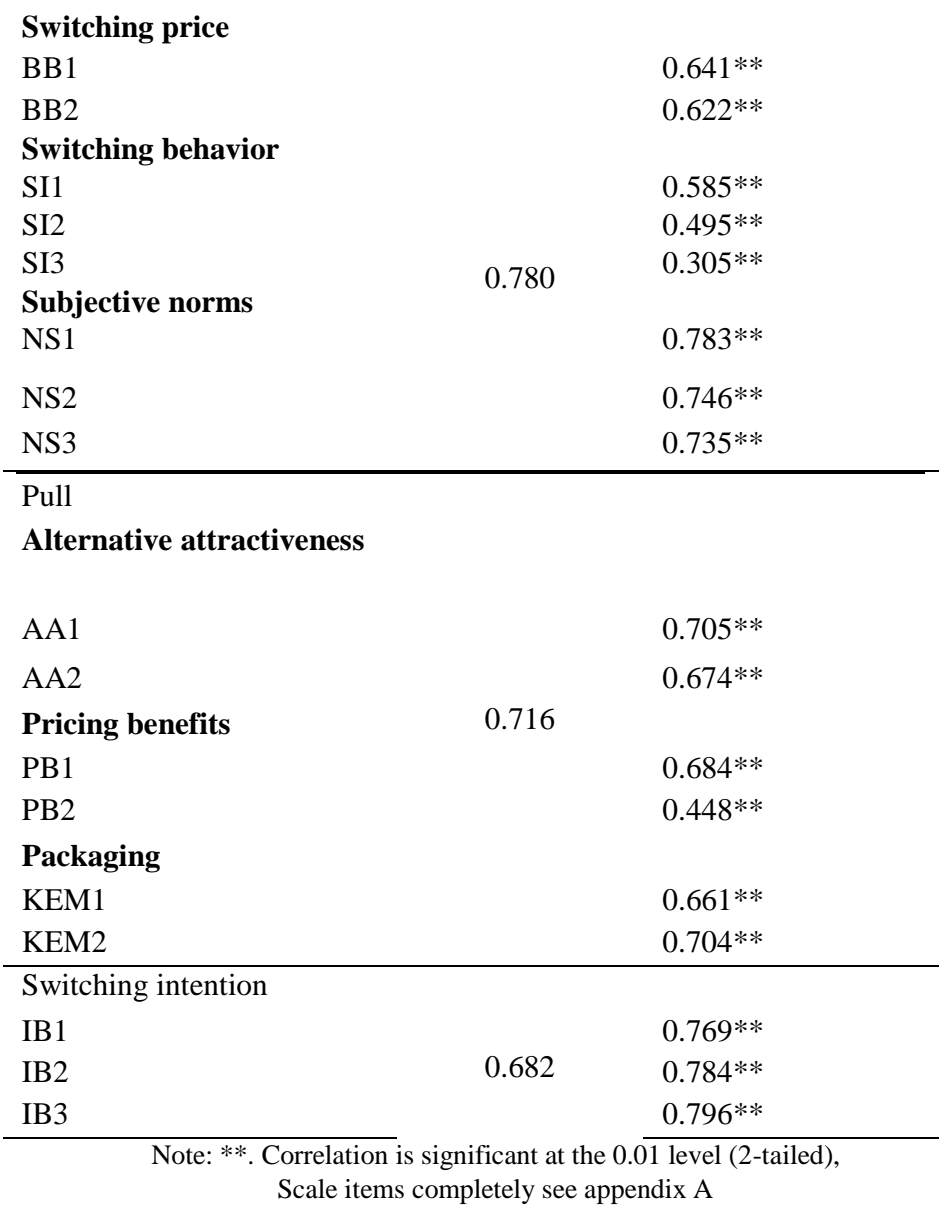

\subsection{Structural Equation Modeling (SEM) Analysis}

\subsubsection{Validity and reliability construct test}

Table 7. Validity and reliability of the measurement model

\begin{tabular}{lrc}
\hline \multicolumn{1}{c}{ Items } & VCFA & CR \\
\hline Push & $* * *$ & 0.825 \\
Mooring & $* * *$ & 0.760 \\
SI3 <--- Mooring & 0,323 & \\
Pull & $* * *$ & 0.731 \\
Intention & $* * *$ & 0.554 \\
\hline
\end{tabular}

Note: ***. Correlation is significant at the 0.05 level, VCFA $=$ Validity: Confirmatory factor analysis $\mathrm{CR}=$ Correlation reliability 
Table 7 it can be seen that the measurement equations for each of the push, mooring, pull and intention indicators are able to reflect the latent or valid variables. There is only 1 indicator that has a value of $p>0.05$ is SI3. In the CR column looks all items reliably and consistently because it has a value of $\mathrm{CR}>0.7$, although the item intention has a value of 0.554 .

\subsection{Hypothesis Test}

Hypothesis testing is done after all the testing stages are done. Testing is done first by looking at the goodness of fit. In this equation indicates satisfactory not fit (chi-square: 1193,966, probability 0,000, degree of freedom 0.321, GFI: 0.659, CFI: 0,578, RMSEA:

0,120 and AGFI: 0.599), nevertheless, the equation is classified as marginal fit.

The hypothesis result of each variable likes in figure 4. In the figure, value consists of probability $(\mathrm{P})$ and the critical ratio $(\mathrm{CR})$. All of the hypothesis is significant and be accepted as a research if the value of $C R \geq 1,96$ at significant $P \leq 0.05$ with error $5 \%$ for $\alpha / 2$.

The results of testing the hypothesis as follows.

- H1: Price, quality, satisfaction, and brand equity positively effect on switching intention to halal supplements

The results of the price variable as shown in Figure 4, shows the value of $p=0.45$ and CR $=-0.75$ (accepting H0). Meaning that the price does not significantly influence switching intention. Expensive or cheap prices are not considered by respondents when they want to buy halal supplements.

Quality variables have a positively significant on switching intention (rejecting H0). This can be seen from the probability value of $0.003<0.05$ and CR 3.003> 1.96, meaning that, respondents believe that halal supplements have good quality. Quality, in this case, includes products, raw materials, and benefits for the body. So the three aspects directly encouraged respondents to intend to leave their old supplements not labeled halal to halal supplements. The results of this study are similar to Khalek '(2013) which states that product quality is one of the main factors that must be in the halal food store menu. In addition, quality is also a variable used by Bansal et al (2005) and Jishim (2017) in its PPM research, where quality variables have a significant positive effect on provider switching intention.

Satisfaction variables do not have a significant influence on switching intention (accepting $\mathrm{H} 0$ ). This statement is seen from the probability value and CR is 0,40 and 0,840 . These findings indicate that halal supplement products have not met consumer expectations. That is, supplements that have or are currently being consumed by respondents still provide satisfaction even though they do not have a halal label.

The value of the hypothesis test of brand equity variable is $p=0.54>0.05$, and CR is $0.61<1.96$ (accepting H0), meaning that brand equity does not significantly influence switching intention. This finding shows that even though halal labeled supplement manufacturers have a good reputation, respondents do not yet have the

desire to switch to consuming halal supplements.

- H2: switching cost, attitude, and subjective norms effect on switching intention to halal supplements 
In the switching cost variable, it can be seen that the p-value is $0.374>0.05$ and CR 0.889 $<1.96$ (accepting H0), meaning that the high or low cost incurred for halal labeled supplements does not affect the desire of respondents to consume the product.

While the attitude variable has a positive significant on switching intention (rejecting $\mathrm{H} 0$ ), meaning that the presence of halal supplement products influences the attitude of the respondents to want to buy the product. Attitude variables in marketing science arise based on views on the product either from one's own experience or other factors (Subianto, 2007). Attitude is closely related to consumer behavior, the response in this finding indicates that effective, thorough, and persuasive communication conducted by producers is able to change the positive paradigm of halal supplements. This communication model can be done by producers, especially the marketing and communication division.

Other researchers such as Farlina et al (2015) and Khalek (2013) also mentioned that attitude variables also had a positively significant on the intention to choose food outlets and halal cosmetic and personal care products.

Subjective norms have a positively significant on switching intention (rejecting H0), it can be seen that the $\mathrm{p}$-value is $0.015<0.05$ and $\mathrm{CR}=3.053>1.96$. Subjective norms are one's perception of doing or not doing something. This perception contains considerations that are influenced by external factors such as family, friends, and advertising. The findings above mean that respondents consider taking a halal labeled supplement because it is influenced by family, friend's invitation and advertisements in the media. These results support the research of Bansal et al (2005) on hair stylist service companies and automotive workshops, Jung et al (2017) on aviation services, Khalek (2013) to consumers of food outlets in Malaysia.

- H3: Alternative attractiveness, pricing benefits, and packaging effects on switching intention halal supplements

Alternative attractiveness does not affect switching intention. This can be seen from the pvalue of $0.052>0.05$ and $C R=1.943<1.96$, meaning that even though halal supplement products are varied and easily found in the nearest store, they have not been able to influence respondents to want to buy.

Pricing benefits do not affect switching intention. Shown by the p-value of $0.591>0.05$ and CR of $-0.537<1.96$, meaning that pricing benefits consisting of quality, benefits and low prices have not affected the respondents' desire to consume halal-labeled supplements.

Packaging has a positive and significant effect on switching intention, meaning that the halal label and the variety of packaging sizes can influence the desire of respondents to consume halal supplements. This is consistent with the statement of Rund (2009), that packaging influences marketing strategies as a place of information and communication with customers. Design and innovation in attractive packaging is one of the effective ways that distinguish competing products and can also increase sales (Rettie and Brewer, 2000).

The next discussion is about mooring as a moderation variable, especially for the answer of Hypothesis $4(\mathrm{H} 4)$ and hypothesis (H5). The process of this analysis using K-means cluster method based on mooring effect, divided into two groups are high mooring $\mathrm{N}=102$ and low mooring with $\mathrm{N}=78$. The complete groups see table 9 . 


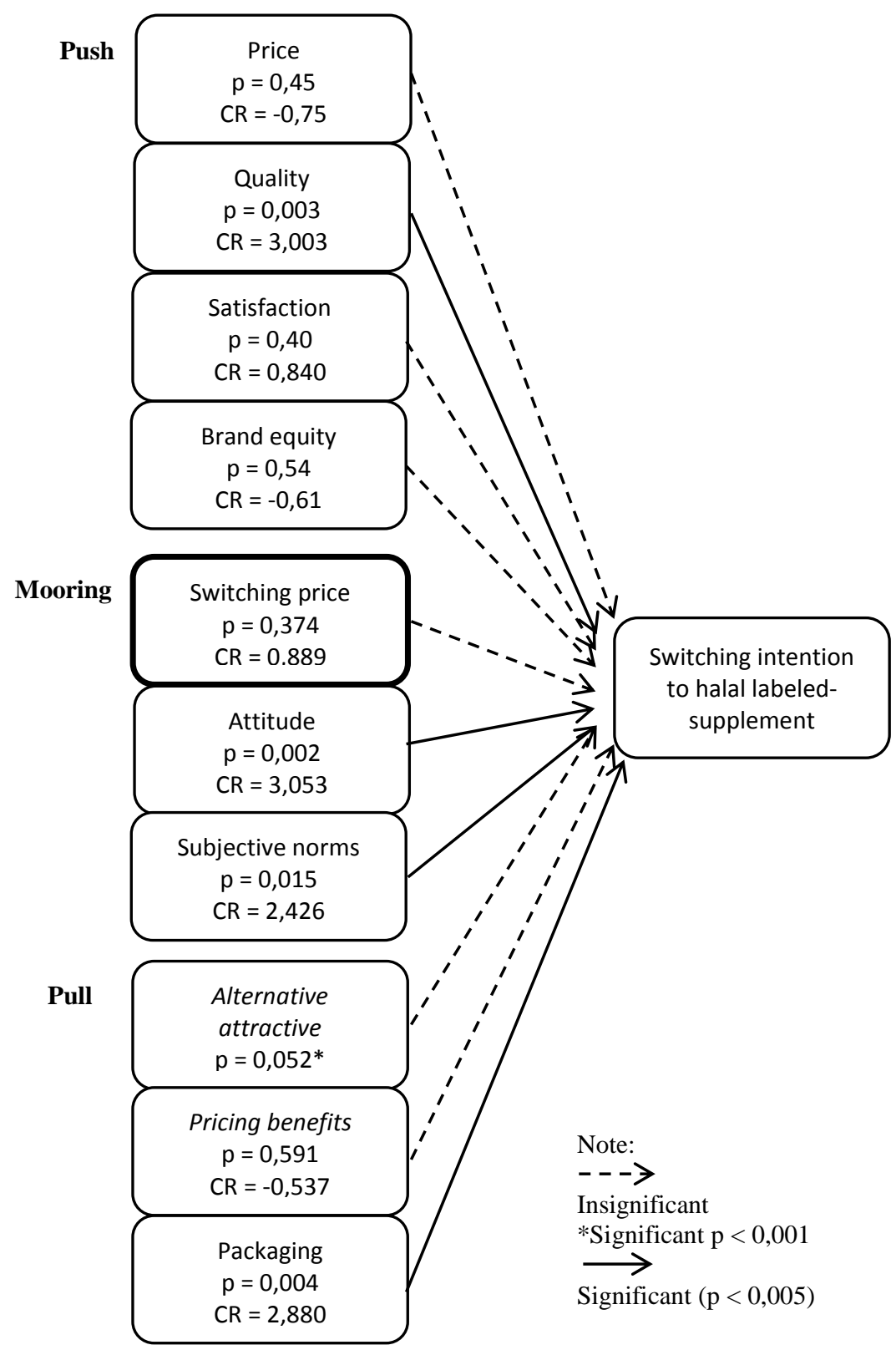

Figure 4. The direct effect of PPM on switching intention to halal - labeled suplement Source: Amos output (processed by the author).

Table 9. Mooring effect as a moderation variable result

\begin{tabular}{lclrrr}
\hline & Variables & & \multicolumn{2}{c}{ High Mooring P* } & \multicolumn{2}{c}{ Low Mooring $\mathbf{P}^{*}$} \\
\hline INTENTION & $<---$ & Push & $* * *$ & $* * *$ \\
INTENTION & $<---$ & Pull &, 004 &, 056 \\
KUA1 & $<--$ & Push & &
\end{tabular}




\begin{tabular}{|c|c|c|c|c|}
\hline HAR3 & $<--$ & Push & ,012 & $* * *$ \\
\hline HAR2 & $<--$ & Push & ,006 & $* * *$ \\
\hline HAR1 & $<--$ & Push & $* * *$ & $* * *$ \\
\hline PB1 & $<--$ & Pull & & \\
\hline AA2 & $<--$ & Pull & $* * *$ & ,002 \\
\hline AA1 & $<--$ & Pull & $* * *$ & ,002 \\
\hline IB1 & $<--$ & Intention & & \\
\hline IB2 & $<--$ & Intention & $* * *$ & $* * *$ \\
\hline IB3 & $<--$ & Intention & $* * *$ & $* * *$ \\
\hline KUA2 & $<---$ & Push & $* * *$ & $* * *$ \\
\hline KUA3 & $<--$ & Push & $* * *$ & $* * *$ \\
\hline KEP1 & $<--$ & Push & $* * *$ & ,018 \\
\hline KEP2 & $<--$ & Push & $* * *$ & $* * *$ \\
\hline EM1 & $<--$ & Push & $* * *$ & $* * *$ \\
\hline EM2 & $<--$ & Push & $* * *$ & $* * *$ \\
\hline PB2 & $<--$ & Pull & , 188 & ,913 \\
\hline KEM1 & $<--$ & Pull & $* * *$ & ,004 \\
\hline KEM2 & $<--$ & Pull & $* * *$ & $* * *$ \\
\hline
\end{tabular}

Table 9 shows the comparison between high mooring groups and low mooring groups. In the high mooring group, the push and pull effect significantly influence on the switching intention to a halal-labeled supplement. Hence, low mooring groups, push effects have a significant effect on switching intention, and the pull effect does not significantly affect the switching intention to halal-labeled supplements. So, the result is in line with fourth our research hypothesis i.e. the mooring variable significantly moderates the relationship between the push effect and switching intention to halal-labeled supplement. The second result is different from fifth hypothesis i.e. pull effect does not significantly affect on the switching intention to halal-labeled, it is similar with findings Bansal et al (2005), Jung et al (2017) and Hou et al (2014).

\section{DISCUSSION}

Based on the hypothesis result test, generally, the results are influential and significant namely, the variable of quality, attitude, subjective norms, and packaging. From the findings, it is expected to provide policy recommendations for the supplement industries and the government.

Influential quality factors in this study, meaning that supplement manufacturers especially the research and development division, need to prioritize the quality of their products, one of which is the selection of raw materials.

Attitude factors are closely related to consumer behavior. The findings show a significant influence on the switching intention. The finding can be a study material for supplement producers, especially the marketing and communication division so as to always make an attractive and persuasive communication model to convince consumers. Because research respondents are millennial Muslim generation, a good method of communication is by utilizing technology, this is in accordance with Guru's statement (2012) that millennial 
generation is a generation characterized by high internet literacy, technological intelligence, and media.

The next variable that is influential is a subjective norm. Perceptions of subjective norms from family, friends, and media considerations can be a reference for producers to increase sales of their products. This finding shows that the millennial generation believed information by word of mouth or in marketing theory known as word of mouth (WOM). This is also mentioned on the website http://goukm.id/strategi-marketing which states that before making a purchase, they will look for reviews or ask their peers who have already made the product, or it can be said that they strongly believe in the power of word of mouth. Thus, producers can model the approach one of them by improving the company's image and improving quality.

Packaging innovation also needs to be considered by the producers. One of the things that can be done is making practical packaging and adjusting to millennial activities that are always active as stated in www.wmfc.org. This statement is in accordance with the survey mentioned on the https://bisnisukm.com/survey website, that millennials prioritize display packaging design compared to taste quality.

In addition, internet marketing methods are an effective step to introduce halal supplements. As according to The West Midland Family Center and Gurau (2012), that the millennial generation is a generation that is technology literate and is inseparable from the use of electronic devices. The use of electronic devices allows them to buy goods online. This does not deny them to buy supplements, then the halal-labeled on the packaging and it is clearly stated in online stalls can be a marketing value-added, besides that halal-labeled supplements can also be a separate marketing niche targeting Muslim communities.

For the government, especially BPOM and LPPOM MUI to be more active in overseeing the distribution of supplements. The quality of halal products is a guarantee for consumers. This is stated in Law Number 33 of 2014 concerning Halal Product Guarantee Chapter 1 Article 3 which states that the implementation of halal product guarantees aims at firstly providing comfort, safety, security, and certainty of the availability of halal products for the community consuming and using products; secondly, increasing added value for businesses to produce and sell halal products. In terms of circulation, it is affirmed in Article 4 that products entering, circulating and trading in the territory of Indonesia must have halal- certificates.

\section{CONCLUSION}

The research is important to the intention of Muslim millennial generation in the Jakarta city and ring road area for switching their supplement. Based on the research, indicate that there are several factors causing the intention of the switching, namely variable of quality, switching behavior, subjective norms, and packaging. While other factors such as price, brand equity, switching price, alternative attractiveness, and pricing benefit have no effects. This is in contrast to the findings of Bansal (2005), Jung (2017), and Nico (2015) which states that all of the variables have an effect, except for mooring moderating variables. The difference these findings is due to the object of the research is a halal-supplement product belonging to the goods sector while their research object is the services sector. In addition, the share of this research is specifically aimed at the Muslim millennial generation which as they were known, is very realistic and quick in purchasing decisions on a product (www.wmfc.org).

These findings are important for both corporate stakeholders and the government. For the company, these findings can be a consideration of the marketing and research development 
division in making targeted strategies the Muslim millennial generation, who is a potential market share in Indonesia. As for the government, mainly BPOM and LPPOM MUI to facilitate halal certification services and supervise the circulation of supplements massively, in order to protect Muslim consumers from raw materials forbidden in Islam.

The research has many limitations, one of them is the object and the location of the research. Therefore, further research is expected to be able to multiply research samples and new theoretic to find out comprehensively findings. In addition, the wellness field is interested to be a research, because the field is currently in the stage of growing and developing.

\section{ACKNOWLEDGEMENT}

This research based on grant scheme of PITTA (Publikasi International Terindeks untuk Tugas Akhir) or also known as Indexed International Publications for Final Projects toward Universitas Indonesia students. Thank you to The Directorate of Research and Community Engagement of Universitas Indonesia (DRPM UI).

\section{REFERENCES}

[1]. Afzaal Ali, Guo Xiaoling, Mehkar Sherwani, Adnan Ali, (2018) "Antecedents of consumers' Halal brand purchase intention: an integrated approach". Management Decision Journal

[2]. Agustina, Liza dan Chandra, Carolina. (2011). Analisis Switching Intention Pengguna Jasa Rumah Kos di Siwalankerto: Perspektif Kualitas Layanan dan Kepuasan Pelanggan. Jurnal Manajemen Pemasaran, Vol. 6, No.1: 22-31.

[3]. Ambali, Abdul Raufu \& Bakar, Ahmad. (2014). People's Awareness on Halal Foods and Products: Potential Issues for Policy-Makers. Procedia -Social and Behavioral Sciences vol 121. 3-25.

[4]. American Educational Research Association, American Psychological Association, \& National Council on Measurement in Education. (1985). Standards for educational and psychological testing. Washington, DC: Authors.

[5]. Azjen, Icek. (1991). The Theory of Planned Behavior. Organizational Behavior And Human Decision Processes vol. 50: 179-211.

[6]. Bansal, H, Taylor, F., James, Y. (2005), "Migrating" to New Service Providers: Toward a Unifying Framework of Consumers' Switching Behaviors, Journal of the Academy of Marketing Science, Vol.33. No.1, pp $96-115$.

[7]. Chen, J.S., Prebensen, N. and Huan, T.C. (2008), Determining The Motivation Of Wellness Travelers, Anatolia, Vol. 19 No. 1, pp. 103-115.

[8]. Davey, A. \& Savla, J. (2010). Statistical power analysis with missing data: A structural equation modelling approach. NewYork: Rouledge Taylor \& Francis Group

[9]. De Hass, Heiden. (2014). Migration Theory Quo Vadis?. Working Papers PAPER 100. International Migration Institute University of Oxford.

[10]. Farlina, Norafni, Shafii, Zurina dan Syahwan, S. (2015). Awareness And Perception Of Muslim Consumers On Halal Cosmetics And Personal Care Products. International Journal of Business, Economics and Management vol 2(1): 1- 14. 
[11]. Gay, L.R. dan Diehl, P.L. (1992). Research Methods for Business and. Management, MacMillan Publishing Company, New York.

[12]. Ghozali, Imam. (2006). Aplikasi Analisis Multivariate dengan Program SPSS. Edisi Kedua. Yogyakarta. Penerbit Universitas Diponegoro

[13]. Global Wellness Economy Monitor (2017).www.globalwellnessinstitute.org. Miami, Amerika Serikat.

[14]. Golob, T. F. (2003). Structural equation modeling for travel behavior research. Transportation Research Part B: Methodological, 37(1).

[15]. Hair, J.F., W.C. Black, B.J. Babin, R.E. anderson, R.L.Tatham, (2009). Multivariate Data Analysis, 7th Ed. New Jersey: Prentice Hall

[16]. Hou, Avus, Shang, Rong, Huaong Chin \& Wu, Kuo. (2014). The Effects Of Push-PullMooring On The Switching Model For Social Network Sites Migration. Proccedings of Pacific Asia Conference on Information Systems (PACIS).

[17]. Hou, A, Chern C, Chen, H \& Chen Y. (2011). Migrating to a new virtual world: Exploring MMORPG switching through human migration theory. Computer in human behavior, 27(5), $1892-1903$.

[18]. Jang, Yoon, Kim Woo dan Bonn Mark (2011). Generation Y consumers' selection attributes and behavioral intentions Concerning green restaurants. International Journal of Hospitality Management vol 30: $803-811$.

[19]. Jezi, Bill. (2015). Pengaruh Push, Pull, Dan Mooring Terhadap Perilaku Beralih Konsumen. Jurnal Berkala Ilmiah Efisiensi vol 15.

[20]. Joseph F Hair, Jr, William C Black, Barry J. Babin, Ralph E Anderson. (2010). Multivariate Data Analysis 7 edition. USA: Pearson Prentice Hall

[21]. Jung, Jishim, Han H \& Oh, Mihae (2017). Travelers' switching behavior in the airline industry from the perspective of the push-pull-mooring framework. Tourism Management vol 59: $139-153$.

[22]. Khalek, Aiedah A. (2012). Young consumers' attitude towards halal food outlets and JAKIM's halal certification in Malaysia. Procedia- Social and Behavio ral Sciences vol 121: $26-34$.

[23]. Melanie Kay Smith, Sonia Ferrari, Laszlo Puczko,(2017), Service Innovations and Experience Creation in Spas, Wellness and Medical Tourism, In The Handbook of Managing and Marketing Tourism Experiences. Published online: 09 Jan 2017; 299319.

[24]. Moskal, Barbara M. \& Jon A. Leydens (2000). Scoring rubric development: validity and reliability. Practical Assessment, Research \&

[25]. Evaluation, 7(10).

[26]. Muijs, Daniel.(2010).Doing Quantitative Research in Education with SPSS. 2nd edition. London: SAGE Publications

[27]. Rettie, R. and Brewer, C. (2000), "The verbal and visual components of package design", Journal

[28]. of Product and Brand Management, Vol. 9 No. 1, pp. 56-70

[29]. Rundh, B. (2009), "Packaging design: creating competitive advantage with product packaging",

[30]. British Food Journal, Vol. 111 No. 9, pp. 988-1002

[31]. Shiv, Charmon dan Ariely. (2005). Placebo Effects of Marketing Actions: 
[32]. Consumers May Get What They Pay For. Journal of Marketing Research vol.42,PP $383-393$.

[33]. Stefan Olof Lagrosen, Kerstin Grundan, (2014), Social Media Marketing In The Wellness Industry, The TQM Journal, Vol. 26 Issue: 3, pp.253 - 260.

[34]. Yeo Bee Li, Rozita Hj. Naina Mohamed, Mazzini Muda. (2016). A Study of Malaysian Customers Purchase Motivation of Halal Cosmetics Retail Products: Examining Theory of Consumption Value and Customer Satisfaction. Procedia Economics and Finance vol 37: $176-182$.

[35]. Surat Keputusan Lembaga Pengkajian Pangan, Obat-Obatan Dan Kosmetika Majelis Ulama Indonesia Tentang Ketentuan Kelompok Produk Bersertifikat Halal MUI Revisi 1. 2014. [Accesed 6th March 2018].

[36]. Survei Centre for Strategic and International Studies 2017. Ada Apa dengan Milenial? Orientasi Sosial, Ekonomi dan Politik. [Online] Available from: https://www.csis.or.id/.../ada_apa_dengan_milenial [Accesed 27th March, 2018]

[37]. www.wmfc.org/uploads/GenerationalDifferencesChart.pdf . [Accesed 24th April, 2018].

[38]. https://www.populationpyramid.net/indonesia/2017/ . [Accesed 23rd March, 2018].

[39]. https://www.urbandictionary.com/define.php?term=Millennial. [Accesed 5th March, 2018].

[40]. http://goukm.id/strategi-marketing-yang-tepat-untuk-membidik-generasi-millennial/. [Accesed 18th August, 2018]

[41]. https://bisnisukm.com/survey-terkini-pasar-milenial-utamakan-desain-kemasanketimbang-rasa.html. [Accesed

[42]. Undang - Undang Nomor 33 Tahun 2014 Tentang Jaminan Produk Halal 